\title{
INTEGRATED CONTINUOUS CARE: IMPLEMENTATION IN MATO GROSSO DO SUL, BRAZIL
}

\author{
CUIDADOS CONTINUADOS INTEGRADOS: IMPLANTAÇÃO EM MATO GROSSO \\ DO SUL, BRASIL
}

\author{
Luciane Perez da COSTA ${ }^{1}$; Edivania Anacleto PINHEIRO' ${ }^{1}$; \\ Robéria Mandú da Silva SIQUEIRA ${ }^{1}$; Beatriz Figueiredo DOBASHI ${ }^{1}$; \\ Maurício Antônio POMPÍLIO ${ }^{1,2}$; Vanessa Terezinha Gubert de MATOS ${ }^{1,3}$
}

1. Hospital São Julião, Campo Grande, MS, Brasil. perezlu10@ hotmail.com; 2. Faculty of Medicine, Federal University of Mato Grosso do Sul, Campo Grande, MS, Brasil; 3. Pharmacy School, Federal University of Mato Grosso do Sul, Campo Grande, MS, Brazil.

\begin{abstract}
The demographic transition that occurred in Brazil brought changes in its health indicators. Integrated Continuous Care (ICC) was organized as a health care model aimed at increasing the independence and well-being of people with acute or recent functional dependence. This study aimed to describe the development and implementation of the Integrated Continuous Care in the state of Mato Grosso do Sul, Brazil. This care model utilized the principles of the National Humanization Policy, such as the extended and shared clinic, embracement, educational practices and meetings with caregivers, families, and patients, open visits, participation and autonomy of the patient and family in the construction of the Singular Therapeutic Project, and shared discharge from hospital. Assistance and support to patients who were already released from ICC must be increased in the primary health care setting to ensure continuity of recovery, better readaptation, and successful family and social reintegration. As a positive result, we set up an outpatient clinic for ICC patients who needed continuous clinical follow-up after rehabilitation. This allows patient re-evaluation, reduces re-admission rates, and maintains the domiciliary care management educational process. As an innovative approach to improving health care outcomes, ICC allows the patients to leave the hospital environment and go home on some weekends. The ICC project has enabled many advances, especially in patient-centered care and shared decision-making. The support of the São Julião Hospital administration has been vital to the success of ICC Unit treatments.
\end{abstract}

KEYWORDS: Rehabilitation. Patient care team. Humanization of assistance. Person-centered care. Shared decision-making.

\section{INTRODUCTION}

After stabilization of acute exacerbation, individuals with noncommunicable chronic diseases are discharged from the hospital. However, many of them present high degree of dependence when performing basic functions (BOYD et al., 2008; BROWN et al., 2009; CHEN et al., 2019; ZISBERG et al., 2015). In order to meet the demands of patients with functional dependence from acute treatment hospitals, long-term care hospital beds in the city of Campo Grande, MS, Brazil were rented. This study aimed to describe the development and implementation trajectory of Integrated Continuous Care (ICC).

Within the period 2000-2060, Brazil's population is expected to reach more than 228 million people by 2042, whereas the population aged 65 years and over will continue to increase until 2060, which accounts for $26.8 \%$ of the total population (BRASIL, 2013). The demographic transition has brought changes to some health indicators. The proportion of individuals living with noncommunicable diseases and the consequences of its injuries are increasing as well as the burden in caring for older patients with complex conditions such as diabetes, respiratory and cardiovascular diseases, and neurological conditions (GBD, 2018). Noncommunicable chronic diseases have direct and indirect impact on the families of affected individuals and those with functional disabilities (MUKA et al., 2015; WHO, 2013).

Germany, Spain (COMAS-HERRERA et al., 2003), Italy, and United Kingdom (MOURA, 2014) recognized the need to respond to the increasing number of older people, and adaptations of the continuous care model in accordance with regional reality were implemented in these countries. Brazil used the ICC Network (ICCN) of Portugal as a guiding model to develop and implement ICC in Brazil. According to the Portuguese version of the Decree-Law No. 101 of June 6, 2006 (PORTUGAL, 2006), ICC involves a range of techniques derived from team evaluation that can meet the health care 
and/or social support demands of elderly patients. This model is focused on achieving global recovery. It is considered as a therapeutic process and social support and is active and continuous. It is aimed at promoting autonomy and enhancing functionality of the person who have functional dependence through rehabilitation, readaptation, and family and social reintegration.

In Brazil, the ICC is referred to as long-term care and is intended for patients who have stable clinical conditions, require rehabilitation, and/or need to adapt to the consequences of clinical, surgical, or traumatic process. It is an intermediary care strategy between acute and chronic hospital care that has been exacerbated and primary health care, including home care, before the patient is discharged from the hospital to its house. Therefore, patients who require rehabilitation or recovery of up to 90 days and fulfill the criteria established by Portaria GM no. 2.809 of December 07, 2012 (BRASIL, 2012) are managed by the ICC Unit (ICCU). The ICCN comprises primary and secondary health care, as well as tertiary hospital and ICCU.

The Program for Support to Institutional Development of the Unified Health System (PROADI-SUS) contributes to the institutional development of the Brazilian Unified Health System (SUS) through the use of technology, project implementation, and provision of professional training interventions, which are carried out by the health entities with a Certificate of Beneficent Entity of Social Assistance in Health (CEBASHEALTH) of Recognized Excellence. All projects are presented by health care entities to the Ministry of Health, which analyzes them with the help of their competent departments or related entities. These projects are executed using the tax exemption amount that these health care entities are entitled due to their CEBAS-SAÚDE status.

In this way, after approval of the ICC project, the State Department of Health Council (CONASS) sent a letter to the different Brazilian states inviting them to adhere to the ICC project and the following four states responded positively: São Paulo, Mato Grosso do Sul, Paraná, and Piauí. Discussions concerning health care region and health care network formation transpired in 2011 when the president of Brazil's Confederation of Mercies and the representative of São Paulo's Santa Casa CEALAG - visited the State Department of Health of Mato Grosso do Sul. ICC was implemented in Mato Grosso do Sul on February 2012 soon after Campo Grande macro-region was declared by the Bipartite Interagency Commission (CIB) of the
State Department of Health as the headquarter city upon its initial implementation.

At the municipal level, the ICC was implemented in the São Julião Hospital. Then, the Hospital Samaritano in partnership with the Ministry of Health and through the PROADI-SUS, signed by the State Department of Health of Mato Grosso do Sul, a technical cooperation term for the implementation of the ICC in the state.

\section{CONTENTS}

São Julião Hospital is part of the National Unified Health System (SUS) that provides outpatient care, in-patient medical and surgical treatment services, diagnostic care, and rehabilitation. It is a medium complexity general hospital with 100 beds; internship, teaching, undergraduate research, and post-graduate research programs are conducted in this hospital. São Julião Hospital was chosen as it had already been operating as a support hospital for high complexity tertiary hospital network since 2009 (DOBASHI, 2014). In 2013, ICCU of São Julião Hospital was accredited through ordinance GM/MS no. 2809 of December 7, 2012 (BRASIL, 2012) according to the current norms of the Ministry of Health for bed accrediting.

CEALAG and Samaritano Hospital provided technical support, while Samaritano and São Julião Hospital allocated financial resources in order to implement this project. Meanwhile, the Ministry of Health conducted the accreditation of the service and released resources for costing that were also apportioned with the municipality and the state.

ICC assistance model is a pilot project that was implemented simultaneously in Pedregulhos and Ipuã, State of São Paulo, in 2013 and in Campo Grande, Mato Grosso do Sul, at the end of the same year. Rebouças, from Paraná State, implemented the project the following year. These cities form the current ICCN (GESAWORLD, 2012). The city of Teresina (Piauí state, Brazil) was initially accepted as part of this network; upon initial implementation, they found that ICC was not applicable in the municipality.

After a technical visit to Portugal and Barcelona in 2012, CEALAG and Gesaworld Group initiated the training of an ICC Unit (ICCU) team of Campo Grande during the period of 2012-2013. Sixteen people from each state of ICCN attended the training course in Barcelona and Portugal, which included representatives from the State and 
Municipal Department of Health, Ministry of Health, and participating hospitals.

The first ICCU was an 8-bed ward called Birds Inn; subsequently, it was able to accommodate 15 beds. Eventually, a new ICCU with 22 beds was constructed. Hospital Samaritano shouldered the expenses of the employees' trainings and purchased the equipment for the new ICCU. São Julião Hospital defrayed all of the expenses of the new unit's construction, which was inaugurated in November 2015. The newly constructed ICCU (named Aldo Rabino) has rooms and various accommodations (such as infirmary, library, refectory, living area, verandas, and areas for podiatry, physiotherapy, occupational therapy, and phonoaudiology), which was in accordance with the ICC guidelines.

Patients admitted in tertiary hospitals (Santa Casa de Campo Grande, Hospital Regional de Mato Grosso do Sul e Hospital Universitário Maria Aparecida Pedrossian) due to urgencies and emergencies are treated immediately until a diagnosis is confirmed and the condition stabilizes. After this phase, the Discharge Management Team (DMT) of each tertiary hospital unit identifies and assesses patients' profile for a possible transfer to ICCU, where treatment is aimed at recovering functional independence and reintegrating the individual to the community (GESAWORLD, 2012).

The DMT can either be part of the core internal regulation with the purpose of identifying patients with ICCU typology, considering all the hospital beds of each partner institution (emergency unit, clinical ward, surgical ward, and intensive care unit) or not. The DMT has to communicate with the staff of its hospital to define ICC patients according to some referral criteria. These criteria include recent functional dependence, need for nursing care, need for rehabilitation, secretion aspiration, need for nasogastric tube feeding, need for ulcer and wound care, presence of stoma, need for parenteral administration, need for oxygen, presence of stable chronic disease with high risk of decompensation, transitory loss of potentially recoverable autonomy, availability of a caregiver, and the acceptance of the transfer to ICCU by the patient. In this way, the participation of teams in the discussion and selection of the most appropriate strategy is unquestionable for the network to operate in Portugal (FERNANDES et al., 2014) and Brazil.

DMT's request for transfer of patient to the ICCU is based on pre-discharge report containing patient data, hospitalization data, and discharge forecasting; medical diagnosis; relevant pathological backgrounds; nursing diagnosis; medications; hospitalization request objectives; ICCU hospitalization period forecast; functional situation; and results of evaluation of social and familial situation. Each DMT consists of at least one doctor, one nurse, and one social worker (GEMITO et al., 2007).

In this context, the physician evaluates the clinical conditions of the patient; the nurse evaluates the treatment needs, devices, and the type of care to be provided to the patient; and the social worker analyzes the viability of the presence of the caregiver accompanying the patient during hospitalization. At least the ICCU doctor and nurse evaluate the pre-discharge report and the clinical conditions of the patient, according to the availability of beds. Depending on the case, reports from other professionals such as physiotherapists, pharmacists, and speech therapists are requested.

The result of this evaluation is forwarded to the DMT with request for more information or authorization for the transfer. When pre-discharge report does not address all problems, it is possible to request information from the DMT. After authorization, DMT formalizes the transfer request for the regulation of hospital beds, and the transfer of the patient from the tertiary hospital network to the ICCU is performed in accordance with the sanitary transport policies of each hospital (BRASIL, 2017).

Fundamental axes of extended clinic have been considered in the ICC model in accordance with the humanization policy for attention and management of SUS. In this way, work process encompasses extended comprehension of healthdisease process and expands work objective. Furthermore, there is shared diagnosis and patient and family co-responsibility for treatment conditions (BRASIL, 2008). For these reasons, admission to ICCU requires the presence of a caregiver or family member during hospitalization who should ideally be any person who will subsequently perform the home care.

The ICC multidisciplinary team consists of doctors, nurses, nursing technicians, pharmacists, nutritionists, physiotherapists, psychologists, social workers, occupational therapists, speech therapists, and dentists. A member of the multidisciplinary team carries out admission at ICCU; afterwards, each health professional reviews the information contained in the pre-discharge report. For development of activities, protocols on decannulation, anticoagulation, incontinence, wound prevention, and treatment were elaborated during training and over the first year of operation, 
involving São Julião Hospital's ICC team, CEALAG's facilitators, and DMT. The assessment tools utilized were pre-established evaluative scales available for use in the health care area, which allowed measurement of patients' level of evolution using basic instrument to daily life activities, mental state, social risk, comorbidities, risk of ulcers by pressure, balance and gait, fragility, and caregiver overload (MORAES, 2016). Until 2019, no postdischarge assessment instrument has been proposed considering the interaction between primary and secondary health care.

After patient admission, the nursing team carries out embracement, promoting good ambience, with guidance on the unit characteristics, facilitating patient and family connection with support services. From embracement until discharge, the ICC's assistance teams perform their activities in a humanized manner, respecting all employees of the institution, patients, and caregivers. Humanizing means including differences in management and care processes, enhancing collaboration and determining new ways of caring and organizing work. Patients are identified by name. The patients are not identified by bed numbers or disease codes during treatment or technical discussions (CHERNICHARO et al., 2013). In an integrated, articulated, and systematic approach, patients may be transferred in different units and handled by different teams, which will help them distinguish themselves based on the specific care provided.

In the first 48 hours of hospitalization, all members of the multidisciplinary team evaluate the patient. After evaluation, the team plans the Singular Therapeutic Project (STP). STP is a tool used by extended clinic that helps in the transition of the medical-centered model into a biopsychosocial model (humanized extended clinic). In the construction of strategies that will guide care and integral attention, the STP is a tool that favors the interlocution between the health care team, patient, and family (BRASIL, 2008).

STP includes identification of problems, definition of objectives, and goals to be reached according to each individual's need for rehabilitation and expected period of hospitalization, which varies from 15 to 60 days. After STP construction, treatment and period of hospitalization is discussed with patient and family. Every 15 days of hospitalization, the multidisciplinary team carries out re-evaluations, and protocols are reapplied to monitor patient evolution, difficulties, and the need for therapeutic plan adjustment. If necessary, STP is modified and discussed again with the family and the patient, whose autonomy is preserved (PINHO et al., 2016).

The caregiver or family member is part of patient-centered care. Exchange of knowledge between the multidisciplinary team, patient, and caregiver during hospitalization empowers caregivers to be autonomous in the care of patients, co-responsibility for the treatment and conditions associated with the care of the family member under their responsibility. Thus, this process of health education conducted by the multidisciplinary team is held regularly on Mondays during the caregivers' meeting and, when necessary, on Saturdays with all family members to allow everyone's participation in the rehabilitation process.

Relevant topics on realities experienced within the period of hospitalization as well as educational practices that promote self-care in relation to basic activities are discussed during caregivers' meeting. Meetings begin with presentation of participants and the theme of the day, followed by the performance of activities based on an active model. At the end of the meeting, peer assessment and activity evaluation are conducted, in which caregivers are invited to suggest themes to be addressed in the next meeting (SIQUEIRA et al., 2017).

When the patient has preserved autonomy, even if he/she is physically dependent, he/she is involved in continued care, becoming a participant in the process and taking responsibility for the promotion of his own health. Throughout the assistance period, all the professionals of the multidisciplinary team must consider particularities of each family or caregiver, promoting care based on hospital care protocols required by SUS, but also individualized attention as per needs and reality of each family and peculiar emotions and characteristics resulting from cultural, social, and economic conditions of each family nucleus (FERNANDES et al., 2014; COSTA, 2016).

The team has used other lightweight technologies in patient's treatment such as therapeutic ride. Professionals of São Julião Hospital's ICCU instituted therapeutic ride in an attempt to comprehend, in practice, difficulties that family and patients would encounter during hospital discharge. Therapeutic ride happens during one or more weekends, and the family is oriented on care assistance procedures to be performed during the period. Upon return to the hospital, the family reports difficulties experienced and are reoriented by the multidisciplinary team (PINHO et al., 2016).

With regard to extended visits, São Julião Hospital offered more time for visiting hours and 
shifting of caregiver and allowed children less than 12 years old and pets during visiting hours. This process has been evaluated positively, giving flexibility, satisfaction, and an expanded participation of family, friends, and caregivers. Moreover, the hospital's physical structure facilitates moments shared with pets without harming the other patients (DOBASHI, 2014).

All needs identified in the patients by a member of the multidisciplinary team are analyzed, considering mainly how these privileges can contribute to the patient's recovery. An example of this privilege was the regularization of marital relations at the church of the institution in 2014, as requested by a bride who was admitted at the ICCU.

In post-discharge, the ICCN involves referral and counter-referral teams, besides family and community (MORAES, 2016). The ICCU multidisciplinary team plans the pre-discharge and send the report within 15 days prior to discharge to the patient's sanitary district. The sanitary district sends the report to the primary care unit or family health strategy, favoring the organization of the service to meet the needs of this new patient. When the patient is discharged at the end of the stipulated treatment or rehabilitation period, he/she takes with him or her the discharge reports from each professional category that attended the patient. However, the multidisciplinary team provides information during hospitalization as well as constant communication assists in the health education process and avoids information overload at the moment of discharge (ISRAEL; TEIXEIRA; ANDRADE, 2011).

For patients residing in the interior of the state, the flow comprises the sending of predischarge and discharge instructions to the Municipal Department of Health of the respective municipality, and this contact is carried out by the ICC social worker. In addition, the patient receives all the guidelines to look for the Municipal Department of Health and to deliver the documents that need the accompaniment in the city of origin and possible requests of services that must be scheduled by this municipality. Date is scheduled for return in the outpatient clinic of egress from Hospital São Julião.

In 2015, the ICC outpatient clinic was opened, which is intended for patients who, after ICCU discharge, need clinical follow-up or revisions and changes in drug treatment according to ICCU physicians' determination. In this outpatient clinic, there is no spontaneous demand for scheduling of appointments. Each patient referred to this service goes through a monthly medical consultation on a pre-established date. The services provided in this outpatient clinic are fully financed by the Hospital São Julião, once no government financial agreement was signed.

Most of the patients attended in ICCU have low purchasing power and difficulties to continue post-hospital treatment, due to a considerable degree of dependence and lack of transport. After the request of the ICCU, the patients residing near the Regional Hospital of Mato Grosso do Sul and those who have difficulties with transportation are assisted by the multidisciplinary team of the Home Care Service of Regional Hospital, which guarantees the continuity of rehabilitation. The other patients are cared by the multidisciplinary team of the Family Health Support Centers (NASF), which includes a physiotherapist whose activity consists of evaluating and suggesting physical adaptations in the home environment.

During assistance through ICC, some patients need to return to the hospital of origin whether due to worsening of health condition or for complementary examinations, whereas re-admission at the ICCU may happen after stabilization of clinical signs. Aiming to keep good communication and problem solving, monthly meetings between ICC team and DMT are conducted (COSTA, 2016).

CEALAG suggested that a conducting group should be created with the main objective of holding meetings to exchange experiences between the network teams and guarantee the effective communication between them. This group is made up of representatives from the DMT of São Julião Hospital, Santa Casa de Campo Grande, Hospital Regional de Mato Grosso do Sul e Hospital Universitário Maria Aparecida Pedrossian, the State Department of Health (SES), the Municipal Department of Health (SESAU), and the ICCU. The primary attributions of the group are to support in the organization of the work processes directed to the operation of the ICCU, identify and support the solution of possible critical points in the progress of ICCU activities, and monitor and evaluate the process of agreement and execution of the network. Meetings are held monthly with pre-defined topics to be discussed, which are previously forwarded to the members of the conducting group. The conducting group are assigned to discuss the cases submitted by the DMT, access criteria, referral flows, communication with the counter-reference services, or any other demand that may arise during the meetings.

In general, the initial proposal was built for the care of the elderly with functional dependence, similar to the ICC in Europe. However, when 
receiving the first patients, it was observed that most of the patients were young adults. Among the challenges to the implementation of the ICC were poor communication between the state and municipal managers, between the hospital of implementation and the reference hospitals (tertiary hospital network), and between the employees of the same institution, mainly DMT, and the care team regarding patient referral. Other difficulties encountered include changes in the management of the Department of Health and hospital institutions during implementation, requiring renegotiation; the difference between the financing sources of the Brazilian health care system and those of the Portugal and Spain health care system; and the limited Brazilian financial resources, mainly for the hospital structuring of the ICCU.

In the primary health care setting, assistance and support to patients already released from ICC need to be strengthened in order to ensure continuity of recovery, better readaptation, and successful family and social reintegration. The transformation process and shared decision making with patients should be implemented continuously in the primary health care setting and in the state's countryside. Elaboration of a post-discharge evaluation instrument considering primary and secondary health care is also important to assess the continuity of these patients' evolution, as well as primary care performance.
Most patients who were attended at the ICCU have low purchasing power and difficulties in continuing post-hospital treatment, due to a considerable degree of dependence and lack of transport. The city of Campo Grande does not have a wide coverage of medical transport service, which makes it unfeasible to continue rehabilitation care in many cases.

As a positive result, we set up an outpatient clinic for ICC patients who needed continuous clinical follow-up after rehabilitation. It allows patient re-evaluation, reduces re-admission rates, and maintains the domiciliary care management educational process. Moreover, embracement; participation of caregivers, families, and patients in decisions about therapy, as well as the conduct of meetings, visitations, presence of friends and relatives during hospitalization, and institution of therapeutic ride, besides elaboration and achievement of the STP by a multidisciplinary team that receives management support of Hospital São Julião, are vital to successful treatment experiences at the ICC.

\section{ACKNOWLEDGEMENTS}

The authors wish to thank Mrs. Eloni Basso Rohde, Auditor of Health Services of the State Department of Health of Mato Grosso do Sul, Brazil, for their full support during the implementation of this health care model.

RESUMO: A transição demográfica identificada no Brasil trouxe mudança de indicadores de saúde. Os Cuidados Continuados Integrados (CCI) se formatam como um modelo de assistência que busca aumentar a independência e bem estar das pessoas com dependência funcional aguda ou recente. O estudo tem como objetivo de descrever a construção e implantação dos Cuidados Continuados Integrados no estado de Mato Grosso do Sul, Brasil. Este modelo de assistência utiliza ferramentas da Política Nacional de Humanização, como clínica ampliada e compartilhada, acolhimento, práticas educativas e reuniões com cuidadores, familiares e pacientes, visitas abertas, participação e autonomia do paciente e familiares no projeto terapêutico singular e alta compartilhada. A assistência e o apoio aos pacientes pós-alta CCI precisam ser fortalecidos na rede básica de saúde, a fim de garantir a continuidade da recuperação, readaptação e perfeita reinserção familiar e social. Como resultado positivo, iniciou-se o ambulatório para pacientes egressos do CCI que precisavam de acompanhamento clínico contínuo após a reabilitação. Esse ambulatório permite a reavaliação do paciente, contribui para reduzir a reinternação e mantém o processo educacional de gerenciamento do cuidado domiciliar. Enquanto inovação em saúde para melhorar os resultados dos cuidados de saúde, o CCI permite a saída dos pacientes do ambiente hospitalar para o domicilio em alguns finais de semana. O projeto CCI trouxe muitos avanços, especialmente o cuidado centrado no paciente e a decisão compartilhada. $\mathrm{O}$ apoio da administração do Hospital São Julião tem sido vital para o sucesso dos tratamentos realizados na unidade CCI.

PALAVRAS-CHAVES: Reabilitação. Equipe de assistência ao paciente. Humanização da assistência. Cuidado centrado no paciente. Decisão compartilhada. 


\section{REFERENCES}

BOYD, C. M.; LANDEFELD, C.S.; COUNSELL, S. R.; PALMER, R. M.; FORTINSKY, R. H.; KRESEVIC, D.; BURANT, C.; COVINSKY, K. E. Recovery of activities of daily living in older adults after hospitalization for acute medical illness. J Am Geriatr Soc.v.56, n. 12, p. 2171-2179, Dec. 2008.

https://doi.org/10.1111/j.1532-5415.2008.02023.x

BRASIL. Brasil. Ministério da Saúde. Secretaria de Atenção à Saúde. Núcleo Técnico da Política Nacional de Humanização. Clínica ampliada, equipe de referência e projeto terapêutico singular / Ministério da Saúde, Secretaria de Atenção à Saúde, Núcleo Técnico da Política Nacional de Humanização - 2. ed. - Brasília: Ministério da Saúde, 2008.

BRASIL. Ministério da Saúde. Portaria n. ${ }^{\circ}$ 2.809, de 07 de dezembro de 2012. Estabelece a organização dos Cuidados Prolongados para retaguarda à Rede de Atenção às Urgências e Emergências (RUE) e às demais Redes Temáticas de Atenção à Saúde no âmbito do Sistema Único de Saúde (SUS). Brasília, DF: Ministério da Saúde; 2012.

BRASIL. Ministério do Planejamento, Orçamento e Gestão. Instituto Brasileiro de Geografia e Estatística IBGE. Diretoria de Pesquisas Coordenação de População e Indicadores Sociais. Projeção da população do Brasil por sexo e idade para o período 2000/2060. Agosto de 2013. Disponível em:

ftp://ftp.ibge.gov.br/Projecao_da_Populacao/Projecao_da_Populacao_2013/nota_metodologica_2013.pdf Accessed in 18 Set. 2017.

BRASIL. Ministério da Saúde. Secretaria de Atenção à Saúde. Departamento de Atenção Hospitalar e de Urgência. Manual de implantação e implementação: núcleo interno de regulação para Hospitais Gerais e Especializados [recurso eletrônico] / Ministério da Saúde, Secretaria de Atenção à Saúde, Departamento de Atenção Hospitalar e de Urgência. - Brasília: Ministério da Saúde, 2017. 57p.

BROWN, C. J.; ROTH, D. L.; ALLMAN, R. M.; SAWYER, P.; RITCHIE, C. S.; ROSEMAN, J. M. Trajectories of life-space mobility after hospitalization. Ann Intern Med., v.150, n. 6, p. 372-378, Mar. 2009. https://doi.org/10.7326/0003-4819-150-6-2000903170-00005

CHEN, X. W.; SHAFEI, M. N.; AZIZ, Z. A.; SIDEK, N. N.; MUSA, K. I. Trends in stroke outcomes at hospital discharge in first-ever stroke patients: Observations from the Malaysia National Stroke Registry (2009-2017). J Neurol Sci, Epub ahead of print, Apr. 2019. https://doi.org/10.1016/j.jns.2019.04.015

CHERNICHARO, I. M.; FREITAS, F. D. S.; FERREIRA, M. A. Humanização no cuidado de enfermagem: contribuição ao debate sobre a Política Nacional de Humanização. Rev Bras Enferm, v. 66, n. 04, p. 564-570, July/Aug. 2013. http://dx.doi.org/10.1590/S0034-71672013000400015

COMAS-HERRERA, A.; COSTA-FONT, J.; GORI, C.; DI MAIO, A; PATXOT, C.; PICKARD, L.; POZZI, A.; ROTHGANG, H.; WITTENBERG, R. European Study of Long-Term Care Expenditure: Investigating the sensitivity of projections of future long-term care expenditure in Germany, Spain, Italy and the United Kingdom to changes in assumptions about demography, dependency, informal care, formal care and unit costs. Report to the European Commission, Employment and Social Affairs DG. February 2003. Available at: http://ec.europa.eu/employment_social/soc-prot/healthcare/ltc_study_en.pdf Accessed in: 18 Set. 2017.

COSTA, L. P. Implantação do projeto do cuidado continuado integrado: atuação e percepção multidisciplinar. 112 f. 2016. Dissertação (Mestrado em Biotecnologia) - Curso de Pós-Graduação em Biotecnologia, Universidade Católica Dom Bosco, Campo Grande, 2016.

DOBASHI, B. F. Os caminhos da gestão em saúde em Mato Grosso do Sul: da Reforma sanitária ao COAP. 1. ed, Campo Grande: MS, 2014. 92 p. 
Integrated continuous...

COSTA, L. P. et al.

FERNANDES, A.; BAPTISTA, G.; MARTINS, P. Dificuldades sentidas pelas equipas na referenciação de utentes para a RNCCI. In: $2^{\circ}$ CONGRESSO INTERNACIONAL "NOVOS OLHARES NA SAÚDE”; Chaves: Portugal, 2014. p. 178-188.

GBD 2017 Disease and Injury Incidence and Prevalence Collaborators. Global, regional, and national incidence, prevalence, and years lived with disability for 354 diseases and injuries for 195 countries and territories, 1990-2017: a systematic analysis for the Global Burden of Disease Study 2017. Lancet. v. 392, n. s/n, p. 1789-17858, Nov. 2018. https://doi.org/10.1016/S0140-6736(18)32279-7

GEMITO, M. L.; SİLVIA, M. E.; SILVA, C.A.; MASSAPINA, I. Cuidados Continuados uma prioridade em saúde? Econ sociol., v. 83, n. s/n, p. 67-84, mês n/a, 2007.

GESAWORLD. Relatório do Projeto: Bases para a criação e desenvolvimento de uma Rede de Cuidados Continuados no Estado do Mato Grosso Do Sul: E2. P4 - Modelo de Cuidados Continuados e Estratégias básicas para dar impulso a criação e desenvolvimento do novo modelo. São Paulo: Gesaworld; 2012. CDROM.

ISRAEL, N. E. N.; TEIXEIRA, J. J. V.; ANDRADE, O. G. A percepção do cuidador familiar sobre a recuperação física do idoso em condição de incapacidade funcional. Cien Saude Colet, v. 16, suppl. 1, p. 13491356, mês n/a, 2011. http://dx.doi.org/10.1590/S1413-81232011000700069

MORAES, J. A. A continuidade dos cuidados à saúde das pessoas que participaram do projeto Cuidados Continuados Integrados. 2016. 92f. Dissertação (Mestrado Profissional em Saúde da Família) - Curso de PósGraduação em Saúde da Família, Universidade Federal de Mato Grosso do Sul, Campo Grande, 2016.

MOURA, B. P. O impacto da rede nacional de Cuidados Continuados Integrados (RNCCI) na demora média hospitalar. 2014. 90f. Dissertação (Mestrado em Gestão da Saúde) - Curso de Pós-Graduação em Gestão da Saúde, Escola Nacional de Saúde Pública, Universidade Nova de Lisboa, Lisboa, 2014.

MUKA, T.; IMO, D.; JASPERS, L.; COLPANI, V.; CHAKER, L.; VAN DER LEE, S. J.; MENDIS, S.; CHOWDHURY, R.; BRAMER, W. M.; FALLA, A.; PAZOKI, R.; FRANCO, O. H. The global impact of non-communicable diseases on healthcare spending and national income: a systematic review. Eur $\mathbf{J}$ Epidemiol, v. 30, n. 4, p. 251-277, Apr. 2015. https://doi.org/10.1007/s10654-014-9984-2

PINHO, J. N.; MONTI, L. L.; PAULA, F. M.; SIQUEIRA, R. M. S., SANTOS, S. C., PINHEIRO, E. A. Passeio terapêutico. In: III CONGRESSO DE ENSINO, PESQUISA E EXTENSÃO DA UNIVERSIDADE CATÓLICA DOM BOSCO - SABERES EM AÇÃO, 24 a 26 de outubro de 2016; Campo

Grande: Universidade Católica Dom Bosco, 2016.

PORTUGAL. Decreto Lei no 101 de 6 de Junho de 2006. Cria a Rede Nacional de Cuidados Continuados Integrados. Portugal, 2006.

SIQUEIRA, R. M. S.; LOUREIRO, M. D. R.; FROTA, O. P.; FERREIRA JUNIOR, M. A. A prática de educação em saúde na visão dos cuidadores informais em cuidados continuados integrados. Rev Enferm UFPE online, Recife, v. 11, n. 8, p. 3079-3086, Ago. 2017. https://doi.org/10.5205/reuol.11064-98681-4ED.1108201712

WHO. WORLD HEALTH ORGANIZATION. Global action plan for the prevention and control of noncommunicable diseases 2013 - 2020. Geneva: World Health Organization; 2013 Available at: http://africahealthforum.afro.who.int/IMG/pdf/global_action_plan_for_the_prevention_and_control_of_ncds_2 013-2020.pdf Accessed in 18 Set. 2017.

ZISBERG, A.; SHADMI, E.; GUR-YAISH, N.; TONKIKH, O.; SINOFF, G. Hospital-associated functional decline: the role of hospitalization processes beyond individual risk factors. J Am Geriatr Soc., v. 63, n. 1, p. 55-62, Jan 2015. https://doi.org/10.1111/jgs.13193 